\title{
Tocolytic action and underlying mechanism of galetin 3,6-dimethyl ether on rat uterus
}

\author{
Juliana da Nóbrega Carreiro', lara Leão Luna de Souza', Joedna Cavalcante Pereira', \\ Luiz Henrique César Vasconcelos ${ }^{1}$, Rafael de Almeida Travassos ${ }^{1,2}$, Barbara Viviana de Oliveira Santos ${ }^{1,3}$ \\ and Bagnólia Araújo da Silva $1,3,4^{*}$
}

\begin{abstract}
Background: Galetin 3,6-dimethyl ether (FGAL) is a flavonoid isolated from aerial parts of Piptadenia stipulacea. Previously, FGAL was shown to inhibit both carbachol- and oxytocin-induced phasic contractions in the rat uterus, which was more potent with oxytocin. Thus, in this study, we aimed to investigate the tocolytic action mechanism of FGAL on the rat uterus.

Methods: Segments of rat uterus ileum were suspended in organ bath containing modified Locke-Ringer solution at $32{ }^{\circ} \mathrm{C}$, bubbled with carbogen mixture under a resting tension of $1 \mathrm{~g}$. Isotonic contractions were registered using kymographs and isometric contractions using force transducer.

Results: FGAL was more potent in relaxing uterus pre-contracted with oxytocin than with $\mathrm{KCl}$. Additionally, FGAL shifted oxytocin-induced cumulative contractions curves to the right in a non-parallel manner, with $\mathrm{E}_{\max }$ reduction, indicating a pseudo-irreversible noncompetitive antagonism of oxytocin receptors (OTR) or a downstream pathway target. Moreover, FGAL shifted $\mathrm{CaCl}_{2}$-induced cumulative contraction curves to the right in a non-parallel manner in depolarizing medium, nominally without $\mathrm{Ca}^{2+}$, with $\mathrm{E}_{\max }$ reduction, suggesting the inhibition of $\mathrm{Ca}^{2+}$ influx through $\mathrm{Cav}_{v}$. The relaxant potency of FGAL was reduced by $\mathrm{CsCl}$, a non-selective $\mathrm{K}^{+}$channel blocker, suggesting positive modulation of these channels. Furthermore, in presence of apamin, 4-aminopyridine, glibenclamide or $1 \mathrm{mM} \mathrm{TEA}^{+}$, the relaxant potency of FGAL was attenuated, indicating the participation of $S K_{C a} K_{V}, K_{A T P}$ and highlighting BK$K_{C a}$. Aminophylline, a non-selective phosphodiesterase (PDE) blocker, did not affect the FGAL relaxant potency, excluding the modulation of cyclic nucleotide PDEs pathway by FGAL.
\end{abstract}

Conclusion: Tocolytic effect of FGAL on rat uterus occurs by pseudo-irreversible noncompetitive antagonism of OTR and activation of $\mathrm{K}^{+}$channels, primarily $\mathrm{BK}_{\mathrm{Ca}}$, leading to calcium influx reduction through $\mathrm{Cav}_{\mathrm{v}}$.

Keywords: Galetin 3,6-dimethyl ether, Flavonoid, Tocolytic action, lon channels, Rat uterus

\section{Background}

Natural products have played an important role in the process of discovery and drug development [1]. These products and their derivatives represent more than 50\% of all drugs in clinical use worldwide, and plants contribute no less than $25 \%$ of this total [2]. In this context, several natural products have been isolated from species

\footnotetext{
* Correspondence: bagnolia@ltf.ufpb.br

${ }^{1}$ Programa de Pós-graduação em Produtos Naturais e Sintéticos Bioativos (PPgPNSB), Universidade Federal da Paraíba (UFPB), João Pessoa, Paraíba, Brazil

${ }^{3}$ Departamento de Ciências Farmacêuticas, Universidade Federal da Paraíba (UFPB), João Pessoa, Paraíba, Brazil

Full list of author information is available at the end of the article
}

of the Fabaceae family, including benzofuranoids, essential oils, triterpenoids, alkaloids and flavonoids [3].

This family includes a plant found in the northeastern Brazilian province of Caatinga, the species Piptadenia stipulacea (Benth.) Ducke, popularly known as "Juremabranca" [4], "Jurema-malícia-da-serra", "Caracará" and "Calumbi" [5]. This species is widely used in folk medicine for treatment of inflammatory processes, being consumed as a decoction or tincture of its barks and leaves [6].

Flavonoids are low molecular weight phenolic compounds, secondary metabolites found in plants [7]. A flavonoid named galetin 3,6-dimethyl ether (FGAL) (Fig. 1) was isolated from the chloroform phase of the 


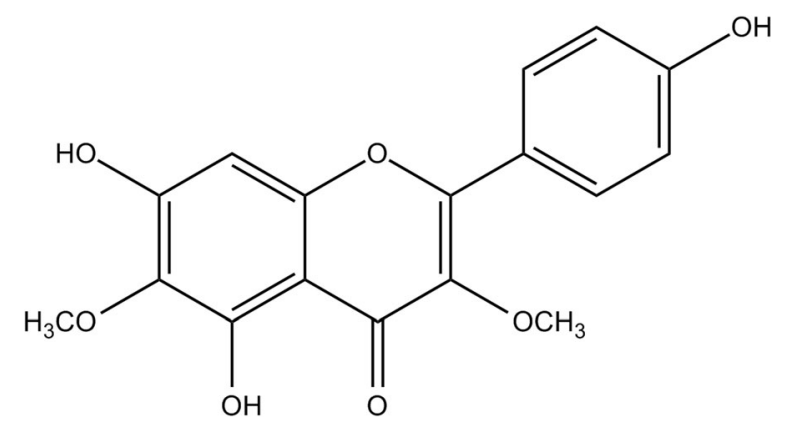

Fig. 1 Chemical structure of flavonoid galetin 3,6-dimethyl ether (FGAL) [8]

crude ethanolic extract obtained from the aerial parts of Piptadenia stipulacea [8]. This flavonoid presented interesting biological activities, such as antiviral [9], anticancer [10] and antioxidant [11]. In addition, the flavonoid presented spasmolytic activity on guinea pig ileum and trachea and rat aorta and uterus [12].

In recent years and in light of the vital importance of myometrium in physiological processes, there has been remarkable progress in the understanding of uterine pathophysiology, such as embryo implantation and disorders such as dysmenorrhea and colic, which occurs by an uncontrolled uterine contractions process [13]. The exaggerated contractions culminate in pain, even leading to reduced uterine vascular flow, hypoxia and ischemia, further increasing the level of pain [14].

Some flavonoids have presented spasmolytic activity in rat uterus, such as genistein, kaempferol, quercetin [15], and isoliquiritigenin, which also showed analgesic activity in mice [16], and FGAL [12], which also presented antiinflammatory and anti-nociceptive activities in mice [8].

Therefore, we decided to investigate the tocolytic action mechanism of FGAL on rat uterus given the importance of flavonoids as secondary metabolites produced by plants, in addition to the fact that substances able to exert tocolytic action are promising for treating uterine pain associated with smooth muscle contraction dysregulation, such as uterine colic and dysmenorrhea.

\section{Methods}

\section{Animals}

Virgin female Wistar rats (40 rats, $150-250 \mathrm{~g}$ ) were used for all experiments. The animals were maintained under standard conditions with a $12 \mathrm{~h}$ light/dark cycle in a temperature-controlled environment $\left(21 \pm 1{ }^{\circ} \mathrm{C}\right)$. They had free access to water and food (Purina ${ }^{\circ}$, Brazil). All experimental procedures were performed in accordance with the guidelines approved by the Animal Research Ethics Committee (CEPA) of Laboratório de Tecnologia Farmacêutica (LTF)/Universidade Federal da Paraíba (UFPB) (protocol n 0303/11).

\section{Chemicals}

FGAL was obtained as previously described [8]. Briefly, FGAL was isolated from the aerial parts of Piptadenia stipulacea Benth., species collected in the city of Serra Branca, Paraíba, Brazil. The sample were identified by $\mathrm{PhD}$. Maria de Fátima Agra, from UFPB. A voucher, Agra et al. 3331 (JPB) was deposited in the Herbarium Lauro Pires Xavier in the Departamento de Sistemática e Ecologia from UFPB (João Pessoa, PB, Brazil).

Potassium chloride $(\mathrm{KCl})$ and calcium chloride bihydrate $\left(\mathrm{CaCl}_{2} \cdot 2 \mathrm{H}_{2} \mathrm{O}\right)$ were purchased from Merck \& Co. Inc. (Whitehouse Station, NJ, USA). Apamin, cesium chloride $(\mathrm{CsCl})$, tetraethylammonium chloride (TEA-Cl), glibenclamide, 4-aminopyridine (4-AP) and diethylstilbestrol were purchased from Sigma-Aldrich Co. (Saint Louis, MO, USA). Oxytocin was purchased from Eurofarma (Brasil). All substances were dissolved in distilled water, except glibenclamide and diethylstilbestrol, which were dissolved in ethanol PA (95\%). FGAL was solubilized in Cremophor $\mathrm{EL}^{\circ}(3 \%)$ plus distilled water. The final concentration of Cremophor $\mathrm{EL}^{\circ}$ in the organ bath never exceeded $0.01 \%(v / v)$, which does not produce any observable effect on rat uterine tonus.

\section{Tissue preparation and measurement of contractile tension}

Rats were pretreated with diethylstilbestrol $1.0 \mathrm{mg} / \mathrm{kg}$ (s.c.) $24 \mathrm{~h}$ prior to the estrus induction experiment. The animals were sacrificed by cervical dislocation. The rat uterus was immediately removed, cleaned of connective tissue and fat and immersed in Locke-Ringer solution (in $\mathrm{mM}: \mathrm{NaCl}, 154.0 ; \mathrm{KCl}, 5.63 ; \mathrm{CaCl}_{2} .2 \mathrm{H}_{2} \mathrm{O}, 2.16$; $\mathrm{MgCl}_{2} .6 \mathrm{H}_{2} \mathrm{O}, 2.10$; glucose, 5.55; and $\mathrm{NaHCO}_{3}, 5.95$ ) [14] and continuously bubbled with a carbogenic mixture $\left(95 \% \mathrm{O}_{2}\right.$ and $\left.5 \% \mathrm{CO}_{2}\right)$. A depolarizing Locke-Ringer solution $(60 \mathrm{mM} \mathrm{KCl})$, nominally without $\mathrm{Ca}^{2+}$, was also used with $\mathrm{KCl}$ in equimolar exchange for $\mathrm{NaCl}$ [15]. The segment of uterus was cut longitudinally into strips ( 1 to $2 \mathrm{~cm}$ in length and approximately $1 \mathrm{~mm}$ wide). Then, the strips were suspended by cotton thread in organ baths at $32{ }^{\circ} \mathrm{C}$. The isotonic contractions were recorded on a drum of a smoky kymograph using lever, and the isometric contractions were registered by a force transducer TIM-50 (São Paulo) coupled to a data acquisition system (AECAD 04F, AQCAD 2.0.3., AVS Projects, SP). The uterus segments were stabilized with a $1.0 \mathrm{~g}$ resting tension (baseline) by at least $40 \mathrm{~min}$. At this time, the solution was changed every $10 \mathrm{~min}$.

\section{Experimental procedures}

FGAL effect on KCl- or oxytocin-induced tonic contractions

After the stabilization period, two similar concentrationresponse curves for $60 \mathrm{mM} \mathrm{KCl}$ or $10^{-2} \mathrm{IU} / \mathrm{mL}$ oxytocin (OXY) were obtained, and after the plateau phase of the 
second contraction, cumulative concentrations of FGAL were added to the organ bath to obtain a relaxation curve. The results were expressed as the reverse percentage of initial contraction elicited by contractile agents. The $\mathrm{pEC}_{50}$ value of FGAL was calculated and compared to both contractile agents.

\section{FGAL effect on oxytocin-induced cumulative contractions}

After the stabilization period, two similar cumulative concentration-response curves for OXY $\left(10^{-5}-3 \times 10^{-1}\right.$ $\mathrm{IU} / \mathrm{mL}$ ) were obtained (control), and then, in the presence of different concentrations of FGAL pre-incubated for $15 \mathrm{~min}$, a third cumulative concentration-response curve for OXY was obtained. The maximal contraction obtained with the control concentration-response curve to OXY was taken as $100 \%$, and all concentrationresponse curves in the presence of FGAL were calculated as a function of this value. $\mathrm{pEC}_{50}$ value of $\mathrm{OXY}$ was calculated in both absence and presence of FGAL concentrations. The antagonism exerted by FGAL was analyzed based on the values of Schild slope [17] and its potency on the $\mathrm{pEC}_{50}$ value.

\section{FGAL effect on $\mathrm{CaCl}_{2}$-induced contractions in depolarizing medium (60 $\mathrm{mM} \mathrm{KCl}$ ) nominally without $\mathrm{Ca}^{2+}$}

After the preparations were stabilized, Locke-Ringer solution was replaced by a depolarizing Locke-Ringer solution, nominally without $\mathrm{Ca}^{2+}$. After $30 \mathrm{~min}, 60 \mathrm{mM} \mathrm{KCI}$ was added to produce smooth muscle depolarization and remained in the bath throughout the experiment. Ten min after KCI addition, two similar cumulative concentration-response curves for $\mathrm{CaCl}_{2}\left(3 \times 10^{-6}-10^{-2}\right.$ $\mathrm{M})$ were obtained (control), and a third cumulative concentration-response curve for $\mathrm{CaCl}_{2}$ was then obtained in the presence of different concentrations of FGAL pre-incubated for $15 \mathrm{~min}$. The $\mathrm{E}_{\max }$ obtained with the control concentration-response curve for $\mathrm{CaCl}_{2}$ was taken as $100 \%$ and served as the reference for all concentration-response curves assessed in the presence of FGAL [15].

\section{FGAL effect on oxytocin-induced tonic contractions in the absence and presence of $K^{+}$channel blockers}

In uterine segments, some pharmacological tools were incubated for $20 \mathrm{~min}$ before the contraction induced by the contractile agent to investigate the participation of different types of $\mathrm{K}^{+}$channels, as follows: $5 \mathrm{mM} \mathrm{CsCl}$, non-selective $\mathrm{K}^{+}$channel blocker [18]; $3 \mathrm{mM}$ 4-AP, voltage-gated $\mathrm{K}^{+}$channel $\left(\mathrm{K}_{\mathrm{v}}\right)$ blocker [19]; $3 \times 10^{-5} \mathrm{M}$ glibenclamide, ATP-sensitive $\mathrm{K}^{+}$channel $\left(\mathrm{K}_{\mathrm{ATP}}\right)$ blocker [20]; $100 \mathrm{nM}$ apamine, small-conductance $\mathrm{Ca}^{2+}$-activated $\mathrm{K}^{+}$channel $\left(\mathrm{SK}_{\mathrm{Ca}}\right)$ blocker [21]; or $1 \mathrm{mM} \mathrm{TEA}^{+}$, big-conductance $\mathrm{Ca}^{2+}$-activated $\mathrm{K}^{+}$channel $\left(\mathrm{BK}_{\mathrm{Ca}}\right)$ blocker [22]. After stabilization of the tonic contraction induced by $10^{-2} \mathrm{IU} / \mathrm{mL}$ OXY, cumulative concentrations of FGAL were added to the bath to obtain the relaxation curve. The results were expressed as the reverse percentage of initial contraction elicited by OXY. The relaxation potency of FGAL was evaluated by comparing the $\mathrm{pEC}_{50}$ values in both the absence and the presence of blockers.

\section{FGAL effect on oxytocin-induced tonic contractions in the absence and presence of non-selective phosphodiesterase inhibitor}

Aminophylline $\left(10^{-4} \mathrm{M}\right)$, a non-selective phosphodiesterase (PDE) inhibitor [23], was added to organ baths for 20 min followed by an OXY-induced tonic contraction, and FGAL was then cumulatively added to obtain the relaxation curve. The results were expressed as the reverse percentage of initial contraction elicited by OXY, and the relaxation potency of FGAL was evaluated by comparing the $\mathrm{pEC}_{50}$ values in both the absence and the presence of aminophylline.

\section{Statistical analysis}

All results were expressed as mean \pm standard error of mean (SEM). Student's t-test, for single comparisons and one-way ANOVA followed by Bonferroni's post-test for multiple comparisons were used in the data analysis, and results were considered significant when $P<0.05$. Curves and $\mathrm{pEC}_{50}$ values were calculated by non-linear regression and Schild slope and $\mathrm{pEC}_{50}$ (negative logarithm to base 10 of molar concentration value of an antagonist that reduces the response to an agonist to $50 \%$ of its maximum effect) by linear regression [17]. All analyses were performed using GraphPad Prism ${ }^{\circ}$ software version 5.01 (GraphPad Software Inc., San Diego, CA, USA).

\section{Results}

FGAL effect on $\mathrm{KCl}$ - or oxytocin-induced tonic contractions

In a concentration-dependent manner, FGAL $\left(10^{-9}-10^{-4}\right.$ $\mathrm{M}, n=5)$ relaxed the uterus pre-contracted with $60 \mathrm{mM}$ $\mathrm{KCl}\left(\mathrm{pEC}_{50}=5.7 \pm 0.06\right)$ or $10^{-2} \mathrm{IU} / \mathrm{mL}$ oxytocin $\left(\mathrm{pEC}_{50}=\right.$ $7.0 \pm 0.08$ ) (Fig. 2). An analysis of the $\mathrm{pEC}_{50}$ values indicates that FGAL was more potent in inhibiting the contractions induced by oxytocin. After the control experiments, all preparations showed complete reversion of the contractile response within $2 \mathrm{~h}$.

FGAL effect on oxytocin-induced cumulative contractions FGAL $10^{-6} \mathrm{M}$ did not present effect, however FGAL $\left(3 \times 10^{-6}\right.$ and $\left.10^{-5} \mathrm{M}, n=5\right)$ inhibited the cumulative concentration-response curves to oxytocin. These curves were shifted to the right in a non-parallel manner, with decreasing $\mathrm{E}_{\max }$ (Table 1, Fig. 3). The FGAL $\mathrm{pEC}_{50}$ ' was $5.04 \pm 0.02$, and Schild slope value was $0.75 \pm 0.16$. 


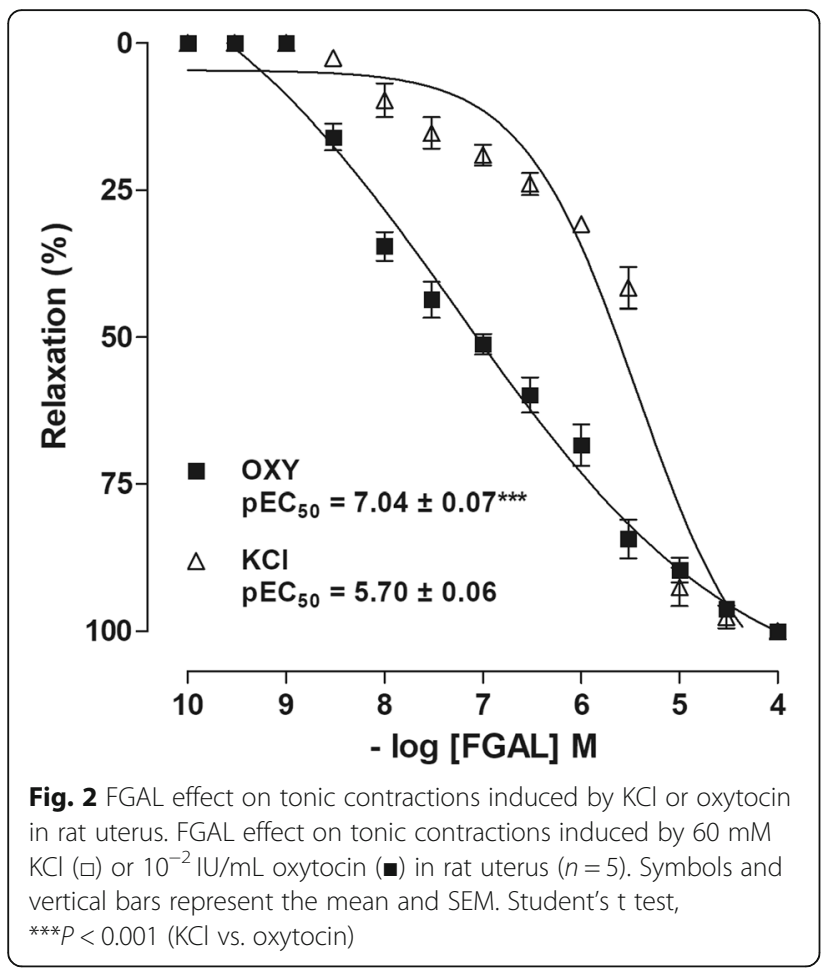

FGAL effect on $\mathrm{CaCl}_{2}$-induced contractions in depolarizing medium, nominally without $\mathrm{Ca}^{2+}$

In depolarizing Locke-Ringer solution, nominally without $\mathrm{Ca}^{2+},(60 \mathrm{mM} \mathrm{KCl})$, FGAL $\left(3 \times 10^{-6}, 10^{-5}\right.$ and $3 \times 10^{-5} \mathrm{M}$, $n=5)$ significantly reduced the $\mathrm{CaCl}_{2}$-induced maximal contractile response and promoted a concentrationdependent rightward shift of $\mathrm{CaCl}_{2}$ concentrationresponse curves (Table 2, Fig. 4).

FGAL effect on oxytocin-induced tonic contractions in the absence and presence of $\mathrm{K}^{+}$channels blockers

FGAL $\left(10^{-9}-10^{-4} \mathrm{M}, n=5\right)$ completely relaxed the uterus pre-contracted with $10^{-2} \mathrm{IU} / \mathrm{mL}$ oxytocin $\left(\mathrm{pEC}_{50}=7.0 \pm\right.$ $0.08)$, but its relaxant potency was attenuated after preincubation with $5 \mathrm{mM} \mathrm{CsCl}\left(\mathrm{pEC}_{50}=5.7 \pm 0.01\right)$ (Fig. 5a). The relaxant potency of FGAL was attenuated in the presence of specific $\mathrm{K}^{+}$channel blockers (Fig. 5b): 3 mM 4-AP $\left(\mathrm{pEC}_{50}=5.5 \pm 0.01\right), 30 \mu \mathrm{M}$ glibenclamide $\left(\mathrm{pEC}_{50}=5.3 \pm\right.$

Table $1 \mathrm{E}_{\max }$ and $\mathrm{EC}_{50}$ values of oxytocin-cumulative contractions curves in absence and presence of FGAL $(n=5)$

\begin{tabular}{lll}
\hline [FGAL] M & $E_{\max }(\%)$ & $\mathrm{EC}_{50}(\mathrm{M})$ \\
\hline Control & 100.0 & $2.7 \pm 0.1$ \\
$10^{-6}$ & 100.0 & $2.9 \pm 0.02$ \\
$3 \times 10^{-6}$ & $65.4 \pm 0.7^{* * *}, \# \# \#$ & $3.1 \pm 0.02^{* *}$ \\
$10^{-5}$ & $0.2 \pm 0.04^{* * *}, \ldots \neq *$ & $\mathrm{Nd}$
\end{tabular}

Data are expressed as the mean \pm S.E.M. $(n=5)$

One-way ANOVA followed by Bonferroni's post-test

${ }^{* *} P<0.05$ and ${ }^{* * *} P<0.001$ (FGAL vs. control): ${ }^{\# \# \#} P<0.001$ (10-6 vs. $3 \times 10-6$

FGAL); ${ }^{¥ ¥ ¥} P<0.001(3 \times 10-6$ vs. $10-5$ FGAL). ND not determined

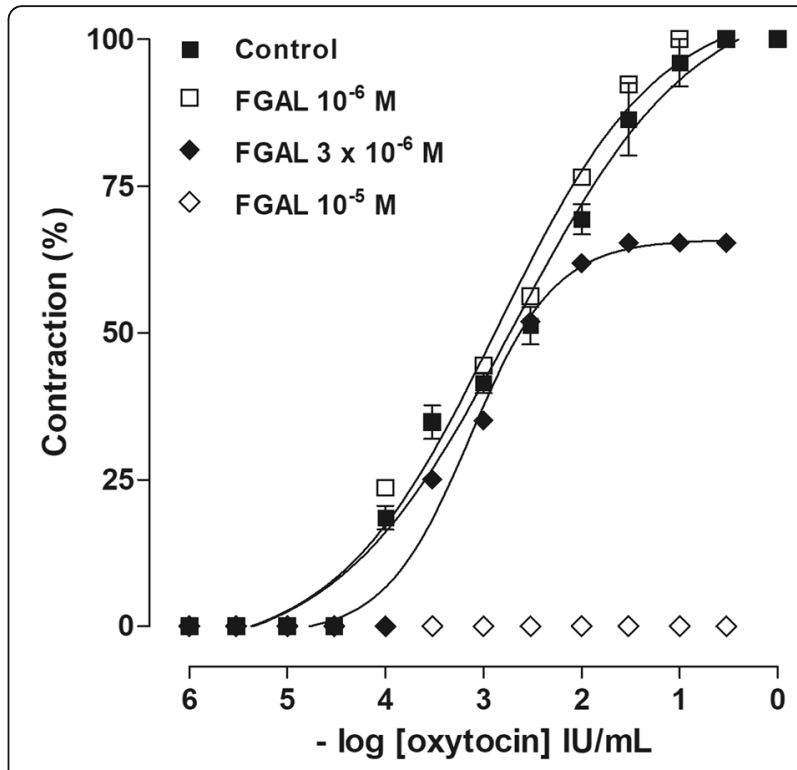

Fig. 3 Cumulative-contractions response curves to oxytocin in absence and presence of FGAL in rat uterus. Cumulativecontractions response curves to oxytocin in the absence $(\boldsymbol{\square})$ and presence of FGAL $10^{-6}(\Delta), 3 \times 10^{-6}(\boldsymbol{\Delta})$ and $10^{-5} \mathrm{M}(\diamond)$ in rat uterus $(n=5)$. Symbols and vertical bars represent the mean and SEM

0.01), $1 \mathrm{mM} \mathrm{TEA}^{+}\left(\mathrm{pEC}_{50}=5.0 \pm 0.009\right)$ and $100 \mathrm{nM}$ apamine $\left(\mathrm{pEC}_{50}=6.4 \pm 0.03\right)$.

FGAL effect on oxytocin-induced tonic contractions in the absence and presence of aminophylline

FGAL $\left(10^{-9}-10^{-4} \mathrm{M}, \mathrm{n}=5\right)$ completely relaxed the uterus pre-contracted with $10^{-2} \mathrm{IU} / \mathrm{mL}$ oxytocin $\left(\mathrm{pEC}_{50}=7.0 \pm\right.$ 0.08 ), and its relaxant potency was not modified in the presence of aminophylline $\left(\mathrm{pEC}_{50}=6.7 \pm 0.03\right)$ when compared with the control curve (Fig. 6).

\section{Discussion}

This study investigated the mechanism of the spasmolytic effect of galetin 3,6-dimethyl ether on rat uterus, which appears to occur by non-competitive pseudo-irreversible antagonism of oxytocin receptors and downstream

Table $2 \mathrm{E}_{\max }$ and $\mathrm{EC}_{50}$ values of $\mathrm{CaCl}_{2}$-cumulative contractions in absence and presence of FGAL $(n=5)$

\begin{tabular}{|c|c|c|}
\hline [FGAL] M & $E_{\max }(\%)$ & $\mathrm{EC}_{50}(\mathrm{M})$ \\
\hline Control & $5.5 \pm 0.4 \times 10^{-5}$ & 100.0 \\
\hline $10^{-6}$ & $6.2 \pm 0.6 \times 10^{-5}$ & 100.0 \\
\hline $3 \times 10^{-6}$ & 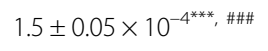 & $83.6 \pm 1.2^{* * *}, \# \#$ \\
\hline $10^{-5}$ & $3.5 \pm 0.4 \times 10^{-4^{* * *},}, ¥ ¥ \neq$ & $23.3 \pm 1.5^{* * *}, ¥ ¥ ¥$ \\
\hline $3 \times 10^{-5}$ & ND & $0.17 \pm 0.03^{* * *}, \S \S \S$ \\
\hline
\end{tabular}

Data are expressed as the mean \pm S.E.M. $(n=5)$

One-way ANOVA followed by Bonferroni's post-test

${ }^{* * *} P<0.001$ (FGAL vs. control); ${ }^{\# \#} P<0.001$ (10-6 vs. $3 \times 10-6$ FGAL);

$¥ ¥ ¥ p<0.001$ ( $3 \times 10-6$ vs. $10-5$ FGAL); ${ }^{\S \S \S} P<0.001$ (10-5 vs. $3 \times 10-5$ FGAL). ND not determined 


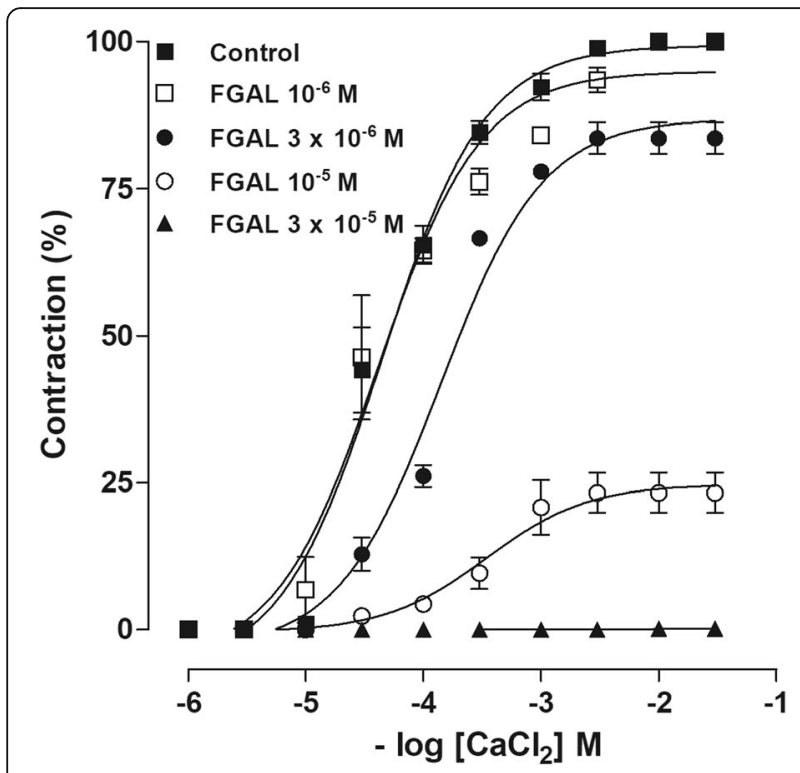

Fig. 4 Cumulative-contractions response curves to $\mathrm{CaCl}_{2}$ in absence and presence of FGAL in rat uterus. Cumulative-contractions response curves to $\mathrm{CaCl}_{2}$ in depolarizing medium, nominally without $\mathrm{Ca}^{2+}$, in the absence $(\boldsymbol{\square})$ and presence of FGAL $10^{-6}(\square), 3 \times 10^{-6}(\bullet), 10^{-5}(\mathrm{o})$ and $3 \times 10^{-5} \mathrm{M}(\boldsymbol{\Delta})$ in rat uterus $(n=5)$. Symbols and vertical bars represent the mean and SEM

pathway modulation, as positive modulation of $\mathrm{K}^{+}$channels, with greatest specificity for $\mathrm{BK}_{\mathrm{Ca}}$ subtype.

In preliminary pharmacological screening, it has been shown that FGAL inhibited both oxytocin- and carbacholinduced phasic contractions in the rat uterus [12]. Thus, we decided to investigate whether the flavonoid would relax the organ pre-contracted by $60 \mathrm{mM} \mathrm{KCl}$, which induces contraction due to electromechanical mechanism and $10^{-2} \mathrm{IU} / \mathrm{mL}$ OXY, a pharmaco-mechanical coupling agent. In a concentration-dependent manner, FGAL relaxed rat uterus pre-contracted by both oxytocin and $\mathrm{KCl}$, but not equipotently, being more potent in relaxing uterus pre-contracted with oxytocin.

Because FGAL was more potent in inhibiting the contractions induced with oxytocin than with carbachol [12] and because it relaxed the rat uterus pre-contracted with this agonist more potently than with $\mathrm{KCl}$, a cumulative concentration-response curves to this agonist were obtained to evaluate a possible antagonism of these receptors. FGAL inhibited oxytocin-cumulative curves, and these were shifted to the right, in a non-parallel manner, with a reduction and abolition of $\mathrm{E}_{\max }$, excluding a competitive antagonism. In addition, the non-competitive antagonism was confirmed, as the slope value $(0.75 \pm 0.16)$ was different from the unit [17].

Non-competitive antagonism occurs when the antagonist binds to the same agonist binding site (pseudo-irreversible antagonism) or in a separate site (allosteric antagonism) [24]. In addition, pseudo-irreversible antagonism occurs with a slow dissociation of the drug from the receptor, leading to a prolonged effect and abolishing the maximum effect of the agonist, differing from those observed in the allosteric antagonism, in which the maximum effect is not suppressed [25]. Thus, the profile of the cumulative concentration-response curves to oxytocin represents a pseudo-irreversible antagonism because the inhibition of the contractile response to oxytocin in the presence of FGAL has not reached a limiting value, a characteristic observed in allosteric antagonism. Additionally, it is not excluded the modulation of downstream pathway, as voltage-gated $\mathrm{Ca}^{2+}$ channels or $\mathrm{K}^{+}$channels.

In rat uterus, extracellular and intracellular $\mathrm{Ca}^{2+}$ sources are important for muscular tonus development, and the $\mathrm{Ca}^{2+}$ entry in smooth muscle cells occurs primarily through voltage-gated $\mathrm{Ca}^{2+}$ channels $\left(\mathrm{Ca}_{V}\right)$ [26].
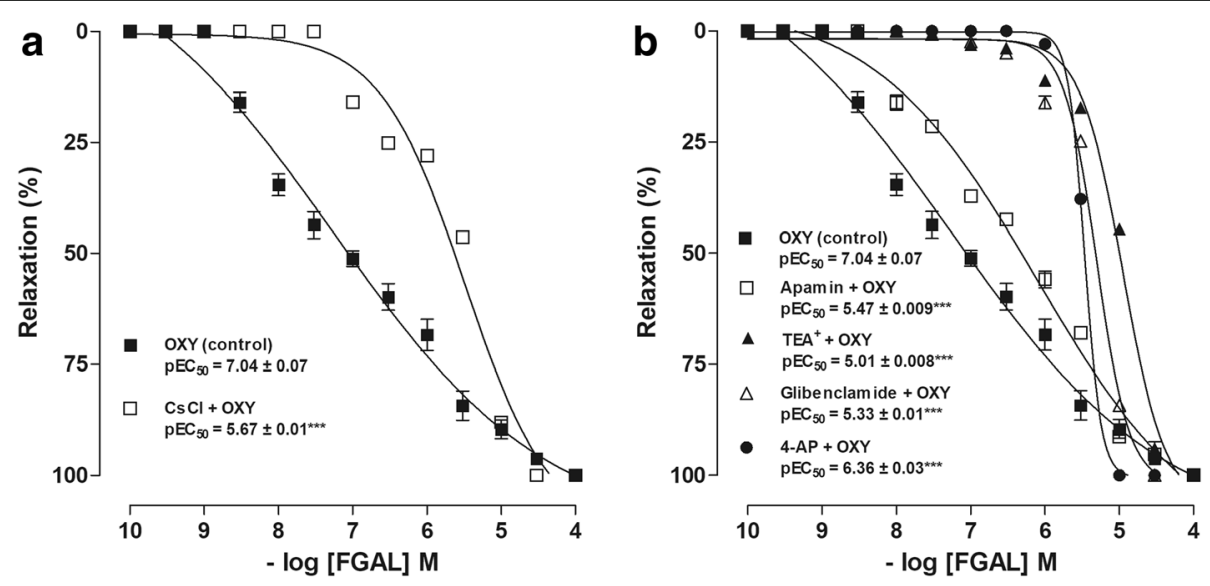

Fig. 5 FGAL effect on tonic contractions induced by oxytocin in absence and presence of $\mathrm{K}^{+}$-channels blockers. FGAL effect on tonic contractions induced by $10^{-2} \mathrm{IU} / \mathrm{mL}$ oxytocin in both absence $(\boldsymbol{\bullet})$ and presence of $\mathrm{CsCl}(\square)(\mathbf{a}), 4-\mathrm{AP}(\boldsymbol{\nabla})$, apamin $(\diamond), 1 \mathrm{mM} \mathrm{TEA}^{+}(\boldsymbol{\nabla})$ or glibenclamide $(\circ)(\mathbf{b})$ in rat uterus $(n=5)$. Symbols and vertical bars represent the mean and SEM, respectively. Student's t test, ${ }^{* * *} P<0.001(\mathrm{OXY}$ vs. blockers + OXY) 


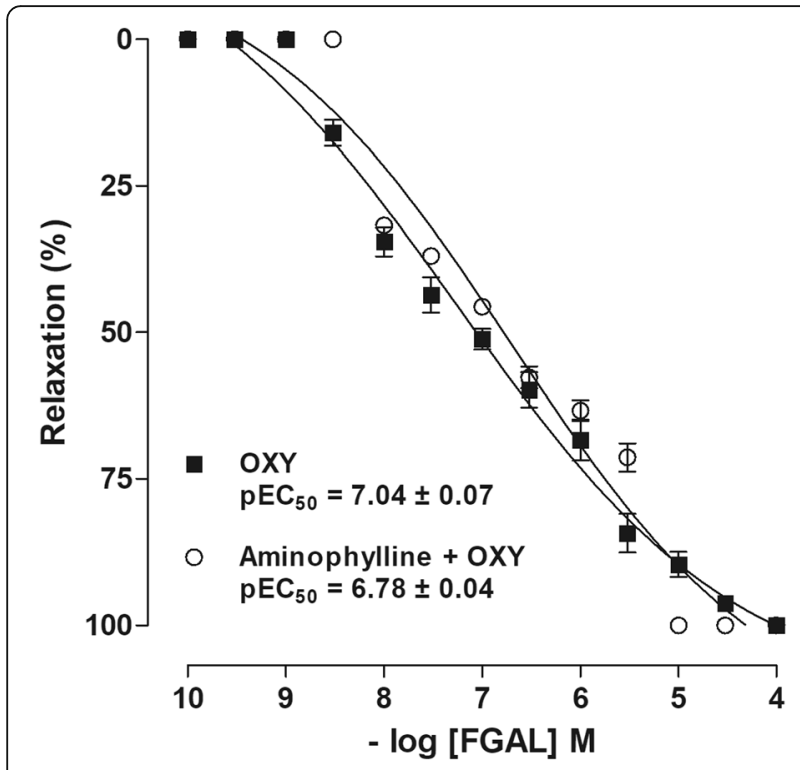

Fig. 6 FGAL effect on tonic contractions induced by oxytocin in absence and presence of aminophylline. FGAL effect on tonic contractions induced by $10^{-2} \mathrm{~J} / \mathrm{mL}$ oxytocin in absence (-) and presence $(\diamond)$ of aminophylline in rat uterus. Symbols and vertical bars represent the mean and SEM, respectively

Because the opening of these channels is a common step in the oxytocin and $\mathrm{KCl}$ signaling pathways to maintain the tonic phase of contraction [27] and because FGAL relaxed the rat uterus pre-contracted by both contractile agents, it was hypothesized that FGAL could be acting by blocking the $\mathrm{Ca}^{2+}$ influx through $\mathrm{Ca}_{\mathrm{V}}$. Therefore, cumulative contractions were induced with $\mathrm{CaCl}_{2}$ in depolarizing medium, nominally without $\mathrm{Ca}^{2+}$ in both the absence and the presence of different concentrations of FGAL. The flavonoid antagonized the $\mathrm{CaCl}_{2}$-induced contractions, as evidenced by the shift of the control curve to the right, in a non-parallel manner, with reduced $E_{\max }$, indicating that the flavonoid inhibits $\mathrm{Ca}^{2+}$ influx through the $\mathrm{Ca}_{\mathrm{V}}$.

The $\mathrm{K}^{+}$channel plays a key role in membrane potential regulation and can modulate the openness of $\mathrm{Ca}_{V}$, regulating the $\mathrm{Ca}^{2+}$ influx in smooth muscle cells [28]. Substances able to open $\mathrm{K}^{+}$channels, such as cromacalin and pinacidil, comprise a diverse group of molecules with therapeutic potential by preventing the cell excitation [29]. These compounds open $\mathrm{K}^{+}$channels, resulting in hyperpolarization by increasing $\mathrm{K}^{+}$efflux, and consequently reduce the cytosolic concentration of $\mathrm{Ca}^{2+}\left(\left[\mathrm{Ca}^{2+}\right]_{\mathrm{c}}\right)$, followed by smooth muscle relaxation [30, 31]. Hence, we decided to investigate the possible positive modulation of these channels using the $\mathrm{CsCl}$, a non-selective $\mathrm{K}^{+}$channel blocker as pharmacological tool [18]. The relaxant potency of FGAL was reduced approximately 22-fold in the presence of $\mathrm{CsCl}$, confirming the positive modulation of $\mathrm{K}^{+}$ channels by FGAL.
In uterine smooth muscle, the most abundant and most studied subtypes of $\mathrm{K}^{+}$channels are $\mathrm{BK}_{\mathrm{Ca}}, \mathrm{SK}_{\mathrm{Ca}}$, $K_{V}$ and $K_{\text {ATP }}$ [32]. Accordingly, we decided to investigate the involvement of these subtypes of $\mathrm{K}^{+}$channels in the tocolytic action of FGAL using selective blockers. The relaxation curve induced by FGAL was shifted to the right in the presence of 4-aminopyridine (36-fold), a selective $K_{V}$ blocker [19], glibenclamide (50-fold), a selective $K_{A T P}$ blocker [20], apamin (4-fold), a selective $\mathrm{SK}_{\mathrm{Ca}}$ blocker [21], and $1 \mathrm{mM} \mathrm{TEA}^{+}$(100-fold), a BK $\mathrm{Ca}$ blocker [22]. These results indicate that these subtypes of $\mathrm{K}^{+}$ channels are involved in the FGAL tocolytic mechanism of action on the rat uterus. Moreover, in the presence of $1 \mathrm{mM} \mathrm{TEA}^{+}$, the relaxant potency of FGAL was more reduced than in the presence of the other blockers, indicating that FGAL primarily positively modulates $\mathrm{BK}_{\mathrm{Ca}}$, which is important because it has been described that uterine smooth muscle presents greater expression of these channels compared with the other subtypes and that they play a fundamental role in regulating the basal tone of this organ [33].

Another important pathway involved in smooth muscle relaxation is the cyclic nucleotide phosphodiesterases (PDEs) pathway. Cyclic monophosphates of adenosine and guanosine (cAMP and cGMP, respectively) are able to activate protein kinase A (PKA) and protein kinase $\mathrm{G}$ (PKG), respectively, when occurs an elevation in the concentration of cAMP and cGMP in the cytosolic medium. These kinases can phosphorylate several intracellular targets, leading to smooth muscle relaxation, and one of these targets are $\mathrm{K}^{+}$channels. PDE is responsible for cAMP and cGMP hydrolysis, resulting in their inactive products $5^{\prime}$-AMP and $5^{\prime}$ GMP, respectively, which do not activate PKA and PKG, thus stopping the cell signaling mechanism dependent on cyclic nucleotides [23]. Substances that raise the intracellular content of cAMP or cGMP show a potential relaxant effect through PDE inhibition in different tissues, including uterine smooth muscle [23].

Thus, to evaluate the involvement of this pathway, aminophylline, a non-selective PDE inhibitor [23], was used as a pharmacologic tool. The FGAL relaxant potency was not altered in both the absence and the presence of aminophylline, suggesting that the cyclic nucleotide PDEs pathway is not involved on relaxing effect induced by FGAL.

\section{Conclusion}

In conclusion, the FGAL tocolytic action mechanism in rat uterus involves a non-competitive pseudo-irreversible antagonism of oxytocin receptors and a positive modulation of $\mathrm{K}^{+}$channels, primarily the $\mathrm{BK}_{\mathrm{Ca}}$ channels subtype, which indirectly modulates the $\mathrm{Ca}_{\mathrm{V}}$, leading to a reduction in $\mathrm{Ca}^{2+}$ influx and uterine smooth muscle relaxation. 
Thereby, FGAL appears promising for the treatment of disorders affecting the uterine smooth muscle, such as the pain caused by colic and dysmenorrhea. However, more research is needed to better elucidate the FGAL tocolytic action mechanism in the rat uterus, such as molecular investigation of ion flow through the channels modulated by FGAL and the effect of FGAL on cytosolic calcium concentration of uterus myocytes.

\section{Abbreviations}

$\mathrm{BK}_{\mathrm{Ca}}$ : Big-conductance $\mathrm{Ca}^{2+}$-activated $\mathrm{K}^{+}$channel; FGAL: Flavonoid galetin 3,6 dimethyl ether; $\mathrm{K}_{\text {ATP }}$ : ATP-sensitive $\mathrm{K}^{+}$channel; OXY: Oxytocin:

PDEs: Phosphodiesterases; $\mathrm{SK}_{\mathrm{Ca}}$ : Small-conductance $\mathrm{Ca}^{2+}$-activated $\mathrm{K}^{+}$channel

\section{Acknowledgements}

The authors thank CAPES and CNPq for financial support and José Crispim Duarte for providing technical assistance.

\section{Funding}

Coordenação de Aperfeiçoamento de Pessoal de Nível Superior (CAPES) and Conselho Nacional de Desenvolvimento Científico e Tecnológico (CNPq).

\section{Availability of data and materials}

Availability of data: no available.

Sample of FGAL: no available.

\section{Authors' contributions}

CJN is the author who mainly contributed to this research, performing literature search, pharmacological experiments, analysis of the data and writing the manuscript. SILL, PJC, VLHC and TRA were involved in acquisition, interpretation and analysis of functional pharmacological experiments. The PhD SBVO performed the phytochemical isolation of the flavonoid studied. The PhD SBA was involved in design, interpretation of the data and review of the manuscript. All authors read and approved the final manuscript.

\section{Ethics approval}

All experimental procedures were performed in accordance with the guidelines approved by the Animal Research Ethics Committee (CEPA) of Laboratório de Tecnologia Farmacêutica (LTF)/Universidade Federal da Paraíba (UFPB) (protocol n 0303/11)

\section{Consent for publication}

Not applicable

\section{Competing interests}

The authors declare that they have no competing interests.

\section{Publisher's Note}

Springer Nature remains neutral with regard to jurisdictional claims in published maps and institutional affiliations.

\section{Author details \\ ${ }^{1}$ Programa de Pós-graduação em Produtos Naturais e Sintéticos Bioativos (PPgPNSB), Universidade Federal da Paraíba (UFPB), João Pessoa, Paraíba, Brazil. ${ }^{2}$ Centro de Biotecnologia, Universidade Federal da Paraíba (UFPB), João Pessoa, Paraíba, Brazil. ${ }^{3}$ Departamento de Ciências Farmacêuticas, Universidade Federal da Paraíba (UFPB), João Pessoa, Paraíba, Brazil. ${ }^{4}$ Centro de Ciências da Saúde/Pós-Graduação em Produtos Naturais e Sintéticos Bioativos/Laboratório de Farmacologia Funcional Prof. George Thomas, Universidade Federal da Paraíba, Cidade Universitária, P.O. Box 5009, João Pessoa, Paraíba 58051-970, Brazil.}

Received: 19 June 2017 Accepted: 14 November 2017 Published online: 02 December 2017

\section{References}

1. Newman DJ, Cragg GM. Natural products as sources of new drugs over the 30 years from 1981 to 2010. J Nat Prod. 2012;75:311-35.
2. Gurib-Fakim A. Medicinal plants: traditions of yesterday and drugs of tomorrow. Mol Asp Med. 2006;27:1-93.

3. Melo AC, Cota BB, Oliveira AB, Braga FC. HPLC quantitation of kaurane diterpene in Xylopia species. Fitoterapia. 2001;72:40-5.

4. Fabricante JR, Andrade LA. Análise estrutural de um remanescente de caatinga no Seridó Paraibano. Oecol Bras. 2007;11:341-9.

5. Florentino ATN, Araújo EL, Albuquerque UP. Contribuição de quintais agroflorestais na conservação de plantas da Caatinga, Município de Caruaru, PE, Brasil. Acta Bot Bras. 2007;21:37-47.

6. Albuquerque UP, Andrade LHC. Uso de recursos vegetais da Caatinga: o caso do agreste do estado de Pernambuco (Nordeste do Brasil). Interciência. 2002;27:336-46.

7. Middleton-Junior E, Kandaswami C, Theoharides TC. The effects of plant flavonoids on mammalian cells: implications for inflammation, heart disease, and cancer. Pharmacol Rev. 2000;52:673-751.

8. Queiroz AC, Lira DP, Dias TLMF, Souza ET, Matta CB, Aquino AB, Silva LHAC, Silva DJC, Mella EAC, Agra MF, Filho JMB, Araújo-Júnior JX, Santos BVO, Alexandre-Moreira MS. The antinociceptive and anti-inflammatory activities of Piptadenia stipulacea Benth. (Fabaceae). J Ethnopharmacol. 2010;128:377-83.

9. Elsohly HN, El-Feraly FS, Joshi AS, Walker LA. Antiviral flavonoids from Alkanna orientalis. Planta Med. 1997;63:384.

10. Rosenbloom RA. Compositions and methods for the treatment of leukemia, Patent Application Publication; 2006. p. 10.

11. Leach D, Stevenson L, Gabriel B, Beattie K. Biologically active compounds isolated from Centipeda and their biological activity as antioxidant and antiinflammatory agents, PCT Patent Filing; 2007. p. 49.

12. Macêdo CL, Vasconcelos LHC, Correia ACC, Martins IRR, Lira DP, Santos BVO, Silva BA. Spasmolytic effect of galetin 3,6 dimethyl-ether, flavonoid obtained from Piptadenia stipulacea (Benth.) Ducke. J Smooth Muscle Res. 2011:47:123-34.

13. Aguilar H, Micthell B. Physiological pathways and molecular mechanisms regulating uterine contractily. Hum Reprod Update. 2010;16:725-44.

14. Bortoleto CCR. Dismenorreia primária, etiopatogenia e terapêutica. Femina. 1995:23:439-43.

15. Revuelta MP, Cantabrana B, Hidalgo A. Depolarization-dependent effect of flavonoids in rat uterine smooth muscle contraction elicited by $\mathrm{CaCl}_{2}$. Gen Pharmacol. 1997;29:847-57.

16. Shi Y, Wu D, Sun Z, Yang J, Chai H, Tang L, Guo Y. Analgesic and uterine relaxant effects of isoliquiritigenin, a flavone from Glycyrrhiza Glabra. Phytother Res. 2012;26:1410-7.

17. Arunlakshana $\mathrm{O}$, Schild $\mathrm{HO}$. Some quantitative uses of drug antagonists. $\mathrm{Br}$ J Pharmacol. 1959;14:48-58.

18. Latorre E, Oberhauser A, Labarca P, Alvarez O. Variety of calcium-activated potassium channels. Annu Rev Physiol. 1989;51:385-99.

19. Aaronson PI, Sarwar U, Gin S, Rockenbauch U, Connolly M, Tillet A, Watson $\mathrm{S}$, Liu B, Tribe RM. A role for voltage-gated, but not $\mathrm{Ca}^{2+}$-activated, $\mathrm{K}^{+}$ channels in regulating spontaneous contractile activity in myometrium from virgin and pregnant rats. Br J Pharmacol. 2006;147:815-24.

20. Hughest SJ, Hollingsworth M. Relaxin as a relaxant of the isolated rat uterus: comparison with its mechanism of action in vivo. Gen Pharmacol. 1997:29:829-33.

21. Tsai ML, Cummings KC, Webb RC, Caruso RL. Acute inhibition of spontaneous uterine contractions by an estrogenic polychlorinated biphenyl is associated with disruption of gap junctional communication. Toxicol Appl Pharmacol. 1998;152:18-29.

22. Jmari K, Mironneau C, Mironneau J. Inactivation of calcium channel current in rat uterine smooth muscle: evidence for calcium- and voltage-mediated mechanisms. J Physiol. 1986;380:111-26.

23. Lugnier C. Cyclic nucleotide phosphodiesterase (PDE) superfamily: a new target for the development of specific therapeutic agents. Pharmacol Ther. 2006;109:366-98.

24. Blumenthal DK, Garrison JC. Pharmacodynamics: molecular mechanisms of drug action. In: Brunton LL, Chabner BA, Knollmann BC, editors. Goodman and Gilman's the pharmacological basis of therapeutics. San Diego: The McGraw-Hill Companies; 2011. p. 41-71

25. May LT, Leach K, Sexton PM, Christopoulos A. Allosteric modulation of $G$ protein-coupled receptors. Ann Rev Pharmacol Toxicol. 2007;47:1-51.

26. Catterall WA. Structure and regulation of voltage-gated $\mathrm{Ca}^{2+}$ channels. Annu Rev Cell Dev Biol. 2000;16:521-55.

27. Wray S. Uterine contraction and physiological mechanisms of modulation. Am J Phys. 1993;264:C1-18. 
28. Knot HT, Brayden EJ, Nelson MT. Calcium channels and potassium channels. In: Bárány M, editor. Biochemistry of smooth muscle contraction. San Diego: Academic Press; 1996. p. 203-19.

29. Quest U, Cook NS. Moving together: $K^{+}$-channel openers and ATP-sensitive $K^{+}$-channels. Trends Pharmacol Sci. 1989;10:431-5.

30. Weston AH, Edwards G. Recent progress in potassium channel opener pharmacology. Biochem Pharmacol. 1992;43:47-54.

31. Brainard AM, Korovkina VP, England SK. Potassium channels and uterine function. Semin Cell Dev Biol. 2007;18:332-9.

32. Lorca RA, Prabagaran M, England SK. Functional insights into modulation of $B K_{C a}$ channel activity to alter myometrial contractility. Front Physiol. 2014;31:1-12.

33. Bender AT, Beavo JA. Cyclic nucleotide phosphodiesterases: molecular regulation to clinical use. Pharmacol Rev. 2006;58:488-520.

Submit your next manuscript to BioMed Central and we will help you at every step:

- We accept pre-submission inquiries

- Our selector tool helps you to find the most relevant journal

- We provide round the clock customer support

- Convenient online submission

- Thorough peer review

- Inclusion in PubMed and all major indexing services

- Maximum visibility for your research

Submit your manuscript at www.biomedcentral.com/submit
Biomed Central 